\title{
Supramolecular Micelle from Amphiphilic Mn(III)-porphyrin Derivatives as a Potential MRI Contrast Agent ${ }^{\dagger}$
}

\author{
Kwangmo Choi, Do-Hyung Lee, and Woo-Dong Jang* \\ Department of Chemistry, Yonsei University, Seoul 120-749, Korea. *E-mail: wdjang@yonsei.ac.kr \\ Received November 27, 2009, Accepted December 5, 2009
}

\begin{abstract}
Amphiphilic porphyrin derivatives have been synthesized and characterized by ${ }^{1} \mathrm{H}$ NMR and MALDI-TOF-MS. All porphyrin derivatives showed very high solubility to aqueous medium as well as hydrophobic organic solvent. The UVvis absorption of the porphyrin derivatives showed significant broadness and decrease of maximum intensity of absorption in aqueous solution. SEM experiment showed the formation of spherical micellar structure. The $\mathrm{T}_{1}$ relaxation time of aqueous medium was drastically decreased in the presence of $\mathrm{Mn}(\mathrm{III})$-porphyrin derivative, indicating that the supramolecular micelle has strong possibility to use as a $\mathrm{T}_{1}$ contrast agent.
\end{abstract}

Key Words: Porphyrin, Self-assembly, Micelle, MRI

\section{Introduction}

Porphyrins ubiquitously exist in animals and plants as key functional molecules for biological activity. ${ }^{1}$ The structure of porphyrin is an aromatic macrocyle formed by 4 pyrrole ring connected with methane bridges. The center of porphyrin can accommodate various metal ions by the coordination to 4 nitrogen atom in pyrrole rings. The metal coordination into porphyrins results in various functional properties, such as electronics, photonics, light-energy conversion, and catalysis. ${ }^{2}$ In the biomedical field, metalloporphyrins are attracting attention as photosensitizers for photodynamic therapy. ${ }^{3}$ Upon a light irradiation, porphyrin derivatives can emit strong fluorescence or generate reactive oxygen species. The strong fluorescence can be utilized as a diagnostic tool for the detection of malignant tissues. And also, the photo-induced reactive oxygen generation can be utilized as a noninvasive treatment of solid tumors. On the other hand, paramagnetic transition metal ion coordinated porphyrin derivatives have been synthesized for the application as MRI contrast agents. Typically, manganese-introduced porphyrin derivatives are currently investigating in clinical availability. ${ }^{4}$ In this context, we have synthesized amphiphilic Mn (III)-porphyrin derivative which formed supramolecular micelle in aqueous medium. ${ }^{5} \mathrm{Mn}$ (III)-porphyrin derivative is expected to be useful as tumor-enhancing agents for MRI due to their high ability to reduce the $T_{1}$ relaxation time. Because the large hydrodynamic volume of supramolecular micelle possibly enhances tumor localization through the enhanced permeability and retention (EPR) effect, ${ }^{6}$ the self-assembled Mn(III)-porphyrin micelle would be very useful for the detection of malignant disease.

\section{Experimental}

General procedures. ${ }^{1} \mathrm{H}$ and ${ }^{13} \mathrm{C}$ NMR spectra were obtained on Bruker DPX-400(400 MHz) spectrometer as solution in

${ }^{\dagger}$ This paper is dedicated to Professor Sunggak Kim on the occasion of his honorable retirement.
$\mathrm{CDCl}_{3}$. TLC was performed on pre-coated silica gel glass plate (silica gel 60, F-254, thickness $0.25 \mathrm{~mm}$ ) by Merck Inc. UV-vis spectra were obtained from JASCO V-660 spectrophotometer. MALDI-TOF MS spectrum data were obtained on Kratos AXIMA-CFR. Platinum-coating for sample scanning electron microscopy (SEM) was taken by Hitachi E-1030, and SEM images were obtained from Hitachi S-4300. The transmission electron microscope (TEM) was performed at $120 \mathrm{kV}$ using JEOL-JEM 2020. The specimens for TEM were prepared by the dropping the solution onto Formvar/Carbon grid (300 mesh, $\mathrm{Cu}, 50 / \mathrm{pKg}$ ) and then dried at room temperature for $24 \mathrm{hrs}$. For the improvement of TEM contrast, $\mathrm{RuO}_{4}$ was used as staining compounds.

Synthesis of PEG dendron. The $2^{\text {nd }}$ generation PEG dendron (4) was synthesized by a previously reported procedure. ${ }^{7}$ Briefly, tri(ethylene glycol) monomethyl ether was reacted with methallyl dichloride in the presence of $\mathrm{NaH}$, and then methallyl group was converted to hydroxyl group using hydroboration reaction to obtain the $1^{\text {st }}$ generation PEG dendron (2). Compound $\mathbf{2}$ was again reacted with methallyl dichloride in the same manner with tri(ethylene glycol)monomethyl ether to obtain 4.

Synthesis of 5: $4(5.5 \mathrm{~g}, 6.3 \mathrm{mmol})$ and $p$-toluenesulfonyl chloride $(3.8 \mathrm{~g})$ was dissolved in dry $\mathrm{CH}_{2} \mathrm{Cl}_{2}(50 \mathrm{~mL})$ and pyridine $(3 \mathrm{~mL})$ and then stirred for $5 \mathrm{hrs}$ at $25^{\circ} \mathrm{C}$. The organic layer was washed with water, and was dried over anhydrous magnesium sulfate. Then the solvent was removed in a rotary evaporator, and the crude product was purified by flash column chromatography to obtain $78 \%$ yield of $5(5.0 \mathrm{~g})$ as yellow oil. ${ }^{1} \mathrm{H} \mathrm{NMR}\left(400 \mathrm{MHz}, \mathrm{CDCl}_{3}\right) \delta 8.30(\mathrm{~d}, 2 \mathrm{H}$; $\mathrm{Ar}-\mathrm{H}), 7.76(\mathrm{~d}, 2 \mathrm{H}$; Ar-H), 4.10 (d, 2 H; Ts-OCH $), 3.29-4.06$ (m, 64 H; - $-\mathrm{OCH}_{2-}-$, 3.37 (s, $12 \mathrm{H}$; $\left.-\mathrm{OCH}_{3}\right), 2.45$ (s, $3 \mathrm{H}$; $\left.-\mathrm{CH}_{3}\right), 2.17-2.04$ (m, $\left.3 \mathrm{H} ; \mathrm{CH}\right)$.

Synthesis of 6: Paraformaldehyde (1.2 g, $40 \mathrm{mmol})$ and pyrrole $(100 \mathrm{~mL}, 1.44 \mathrm{~mol})$ were dissolved in mixture of $\mathrm{AcOH}$ $(150 \mathrm{~mL})$ and $\mathrm{MeOH}(50 \mathrm{~mL})$. The solution was stirred for 20 hrs at $25^{\circ} \mathrm{C}$. After then, the reaction mixture was washed with water $(200 \mathrm{~mL} \times 2)$ and aqueous $\mathrm{KOH}$ solution $(0.1 \mathrm{M} ; 200$ $\mathrm{mL} \times 2)$. The product was purified by flash column chromatography as eluent of $\mathrm{CH}_{2} \mathrm{Cl}_{2}$ to obtain 6 as white crystal in $48 \%$ yield (2.46 g). ${ }^{1} \mathrm{H}$ NMR (400 MHz, $\left.\mathrm{CDCl}_{3}\right) \delta$ 6.06-6.63 (m, 6 $\mathrm{H}$; Ar-H), 3.89 (s, $2 \mathrm{H} ; \mathrm{CH}_{2}$ ). 
Synthesis of 7: To a mixture solution of $6(2 \mathrm{~g}, 13.7 \mathrm{mmol})$, 4- $n$-decyloxylbenzaldehyde (1.89 mL, $6.90 \mathrm{mmol})$, and 4-hydroxybenzaldehyde ( $850 \mathrm{mg}, 6.90 \mathrm{mmol})$ in $\mathrm{CH}_{2} \mathrm{Cl}_{2}(580 \mathrm{~mL})$ and $\mathrm{MeOH}(150 \mathrm{~mL}), \mathrm{BF}_{3} \cdot \mathrm{Et}_{2} \mathrm{O}(2 \mathrm{~mL})$ was added and then stirred for $24 \mathrm{hrs}$ at $25{ }^{\circ} \mathrm{C}$. After then, $p$-chloranil ( $10 \mathrm{~g}, 40.0$ $\mathrm{mmol}$ ) was added to the reaction mixture and further stirred for $12 \mathrm{hrs}$. After removing the solvent, the product was purified by flash column chromatography, followed by recrystallization in $\left(\mathrm{CH}_{2} \mathrm{Cl}_{2} / \mathrm{Hexane}\right)$ to obtain 7 as purple solid in $10 \%$ yield (400 $\mathrm{mg}) .{ }^{1} \mathrm{H}$ NMR $\left(400 \mathrm{MHz}, \mathrm{CDCl}_{3}\right) \delta 10.82(\mathrm{~s}, 2 \mathrm{H}$; meso-CH in Porphyrin), 9.07-9.11 (m, $8 \mathrm{H}$; pyrrole $\beta-\mathrm{H}), 8.75$ (s, $1 \mathrm{H}$; -OH), 8.37-8.44 (q, $4 \mathrm{H} ; \mathrm{C}_{6} \mathrm{H}_{4}$ ), 7.22, 7.36, 8.08, 8.15 (d, $\left.8 \mathrm{H} ; \mathrm{C}_{6} \mathrm{H}_{4}\right)$, 0.92-2.04 (m, $21 \mathrm{H}$; alkyl chain), -2.98(s, $2 \mathrm{H}$; NH).

Synthesis of 8: To a mixture solution of $5(0.32 \mathrm{~mL}, 0.31$ $\mathrm{mmol})$ and 7 (100 mg, $0.155 \mathrm{mmol})$ in DMF (100 mL), $\mathrm{K}_{2} \mathrm{CO}_{3}$ $(138 \mathrm{mg}, 0.8 \mathrm{mmol}$ ) was added and then refluxed for $12 \mathrm{hrs}$. The reaction mixture was poured in water $(200 \mathrm{~mL})$ and then extracted with ethyl acetate $(200 \mathrm{~mL})$. The combined extract was evaporated to dryness. The residue was column chromatographed to obtain 8 of purple liquid in $70 \%$ (161 mg). ${ }^{1} \mathrm{H} \mathrm{NMR} \mathrm{(400} \mathrm{MHz,}$ $\left.\mathrm{CDCl}_{3}\right) \delta 10.30(\mathrm{~s}, 2 \mathrm{H}$; meso-H in porphyrin), 9.11-9.40 (m, $8 \mathrm{H}$, pyrrole $\beta-\mathrm{H}), 8.17-8.18\left(\mathrm{~m}, 4 \mathrm{H} ; \mathrm{C}_{6} \mathrm{H}_{4}\right), 7.31-7.36(\mathrm{~m}, 4 \mathrm{H}$ $\left.\mathrm{C}_{6} \mathrm{H}_{4}\right), 4.35$ (d, $2 \mathrm{H}$; Ph-O-CH $2_{2}$ ), 3.38-3.79 (m, 64 H; - $\mathrm{OCH}_{2}-$ ), 3.31 (s, $12 \mathrm{H}$; $\left.-\mathrm{OCH}_{3}\right), 2.26-2.62(\mathrm{~m}, 3 \mathrm{H} ; \mathrm{CH}), 0.92\left(\mathrm{t}, 3 \mathrm{H} ; \mathrm{CH}_{3}\right)$, 0.91-1.67 (m, $21 \mathrm{H}$; alkyl chain).

Synthesis of 9: To a mixture solution of 6(2.11 g, $14.5 \mathrm{mmol})$, 3,5-dihydroxybenzaldehyde ( $1 \mathrm{~g}, 7.24 \mathrm{mmol})$ and 4-carboxybenzaldehyde $(1.19 \mathrm{~g}, 7.24 \mathrm{mmol})$ in $\mathrm{CH}_{2} \mathrm{Cl}_{2}(640 \mathrm{~mL})$ and $\mathrm{MeOH}(160 \mathrm{~mL}), \mathrm{BF}_{3} \cdot \mathrm{Et}_{2} \mathrm{O}(4 \mathrm{~mL})$ was added and stirred for 20 hrs at $25^{\circ} \mathrm{C}$. $p$-Chloranil $(5.18 \mathrm{~g}, 21.1 \mathrm{mmol})$ was added to the reaction mixture and further stirred for $8 \mathrm{hrs}$. After then, $\mathrm{MeOH}$ solution of $\mathrm{Zn}(\mathrm{OAc})_{2}$ was added to the reaction mixture. After removing the solvent, the product was purified by flash column chromatography, followed by recrystallization in $\left(\mathrm{CH}_{2} \mathrm{Cl}_{2} / \mathrm{He}-\right.$ xane) to obtain 9 as purple solid in $15 \%$ yield $(670 \mathrm{mg}) .{ }^{1} \mathrm{H}$ $\mathrm{NMR}\left(400 \mathrm{MHz}, \mathrm{CDCl}_{3}\right) \delta 10.37$ (s, $2 \mathrm{H}$; meso-H in porphyrin), 8.91-9.53 (m, $8 \mathrm{H}$; pyrrole $\beta-\mathrm{H}), 8.37-8.44$ (q, $\left.4 \mathrm{H} ; \mathrm{C}_{6} \mathrm{H}_{4}\right), 6.68$ and $7.08\left(\mathrm{~s}, 3 \mathrm{H} ; \mathrm{C}_{6} \mathrm{H}_{3}\right), 4.07\left(\mathrm{~s}, 3 \mathrm{H} ;-\mathrm{OCH}_{3}\right)$.

Synthesis of 10: A mixture solution of $9(890 \mathrm{mg}, 1.44 \mathrm{mmol})$, $\mathrm{K}_{2} \mathrm{CO}_{3}(2 \mathrm{~g}, 14.4 \mathrm{mmol})$, and 18-crown-6-ether (760 mg, 0.288 $\mathrm{mmol})$ in dry THF $(140 \mathrm{~mL}), 1$-bromooctane $(5 \mathrm{~mL}, 28.8 \mathrm{mmol})$ was added and then refluxed for $25 \mathrm{hrs}$ under $\mathrm{N}_{2}$. The reaction mixture was poured into water extracted with ethyl acetate. The combined extract was column chromatographed to obtain 10 as pink solid in $71 \%$ yield $(0.86 \mathrm{~g}) .{ }^{1} \mathrm{H}$ NMR $(400 \mathrm{MHz}$, $\left.\mathrm{CDCl}_{3}\right) \delta 10.35$ (s, $2 \mathrm{H}$; meso-H in prophyrin), 9.08-9.47 (m, $8 \mathrm{H}$; pyrrole $\beta-\mathrm{H}), 8.35$ and $8.47\left(\mathrm{~d}, 4 \mathrm{H} ; \mathrm{C}_{6} \mathrm{H}_{4}\right), 7.42(\mathrm{~d}, 2 \mathrm{H} ; o-$ $\left.\mathrm{C}_{6} \mathrm{H}_{3}\right), 6.90\left(\mathrm{~s}, 1 \mathrm{H} ; p-\mathrm{C}_{6} \mathrm{H}_{3}\right), 5.35\left(\mathrm{t}, 4 \mathrm{H} ;-\mathrm{OCH}_{2}-\right), 4.15(\mathrm{~s}, 3 \mathrm{H}$; $\left.-\mathrm{OCH}_{3}\right), 1.27$ (m, $24 \mathrm{H}$; alkyl chain), 0.87 (t, $\left.6 \mathrm{H} ;-\mathrm{CH}_{3}\right)$.

Synthesis of 11: To a THF $(20 \mathrm{~mL})$ solution of $10(850 \mathrm{mg}$, $1.01 \mathrm{mmol}), \mathrm{LiAlH}_{4}(57.6 \mathrm{mg}, 1.52 \mathrm{mmol})$ was slowly added and vigorously stirred for $1 \mathrm{hr}$ at $0{ }^{\circ} \mathrm{C}$. The reaction mixture was poured in water and extracted with ethyl acetate. The combined extract was column chromatographed to obtain $\mathbf{1 1}$ as scarlet solid in $91 \%$ yield $(765 \mathrm{mg}) .{ }^{1} \mathrm{H}$ NMR $\left(400 \mathrm{MHz}, \mathrm{CDCl}_{3}\right) \delta$ 10.32 (s, $2 \mathrm{H}$; meso-H in porphyrin), 9.12-9.44 (m, $8 \mathrm{H}$; pyrrole $\beta-\mathrm{H}), 7.75,8.24\left(\mathrm{~d}, 4 \mathrm{H} ; \mathrm{C}_{6} \mathrm{H}_{4}\right), 7.43\left(\mathrm{~d}, 2 \mathrm{H} ; o-\mathrm{C}_{6} \mathrm{H}_{3}\right), 6.91$ (s, $\left.1 \mathrm{H} ; p-\mathrm{C}_{6} \mathrm{H}_{3}\right), 5.02\left(\mathrm{~d}, 2 \mathrm{H}\right.$; $\left.\mathrm{Ar}-\mathrm{CH}_{2} \mathrm{O}\right), 4.13\left(\mathrm{t}, 4 \mathrm{H}\right.$; $\mathrm{Ar}-\mathrm{OCH}_{2}$ ),
1.88 (m, 4 H; -), 1.25-1.39 (m, $20 \mathrm{H}$; alkyl chain), 0.84 (t, $6 \mathrm{H}$; $\left.-\mathrm{CH}_{3}\right)$.

Synthesis of 12: To a mixture solution of $\mathbf{1 1}(70 \mathrm{mg}, 0.086$ $\mathrm{mmol})$ and $5(0.2 \mathrm{~mL}, 0.12 \mathrm{mmol})$ in THF $(30 \mathrm{~mL}), 60 \% \mathrm{NaH}$ (20 mg, $0.021 \mathrm{mmol}$ ) was added at $0{ }^{\circ} \mathrm{C}$ and slowly warmed to room temperature. And then, the reaction mixture was vigorously stirred for 3 days. The mixture was poured into water and extracted with ethyl acetate. The combined extract was evaporated to dryness and column chromatographed to obtain $\mathbf{1 2}$ as purple solid in $21 \%$ yield $(30 \mathrm{mg})$. UV-vis (THF): $\lambda_{\max } 411$, $543 \mathrm{~nm} ;{ }^{1} \mathrm{H}$ NMR $\left(400 \mathrm{MHz}, \mathrm{CDCl}_{3}\right) \delta 10.32$ (s, $2 \mathrm{H}$; meso-H in porphyrin), 9.15-9.45 (m, $8 \mathrm{H}$; pyrrole $\beta-\mathrm{H}), 7.76,8.28$ (d, $\left.4 \mathrm{H} ; \mathrm{C}_{6} \mathrm{H}_{4}\right), 7.43$ (s, $\left.2 \mathrm{H} ; \mathrm{C}_{6} \mathrm{H}_{3}\right), 6.91$ (s, $\left.1 \mathrm{H} ; \mathrm{C}_{6} \mathrm{H}_{3}\right), 4.89$ (s, $2 \mathrm{H}$; $\left.-\mathrm{PhCH}_{2} \mathrm{O}-\right)$, 4.16 (m, $6 \mathrm{H}$; - $\mathrm{PhOCH}_{2}$ - and $\left.\mathrm{PhCH}_{2}-\mathrm{OCH}_{2}-\right), 3.80$ (d, $2 \mathrm{H}$; - $\left.\mathrm{CH}_{2} \mathrm{O}-\right)$, 2.98-3.65 (m, $48 \mathrm{H}$; - $\mathrm{OCH}_{2}$ - in PEG dendron), 2.86 (s, $\left.12 \mathrm{H} ;-\mathrm{OCH}_{3}\right), 2.25-2.40$ (m, $\left.3 \mathrm{H} ; \mathrm{CH}\right), 1.28-1.89$ (m, 24 $\mathrm{H}$; alkyl chain), 0.86 (t, $6 \mathrm{H} ;-\mathrm{CH}_{3}$ in alkyl chain).

Synthesis of 13: To a solution of $12(5 \mathrm{mg}, 3.01 \mu \mathrm{mol})$ in $\mathrm{CH}_{2} \mathrm{Cl}_{2}(20 \mathrm{~mL})$, trifluoroacetic acid $(2 \mathrm{~mL})$ was added and stirred $5 \mathrm{~min}$. The mixture solution was washed with water $(3 \times$ $20 \mathrm{~mL}$ ) and then column chromatographed to obtain 13 as purple solid in $95 \%$ yield $(4.57 \mathrm{mg}) .{ }^{1} \mathrm{H}$ NMR $\left(400 \mathrm{MHz}, \mathrm{CDCl}_{3}\right) \delta$ 10.31 (s, $2 \mathrm{H}$; meso-H in porphyrin), 9.09-9.41 (m, $8 \mathrm{H}$ pyrrole $\beta-\mathrm{H}), 7.78,8.26\left(\mathrm{~d}, 4 \mathrm{H} ; \mathrm{C}_{6} \mathrm{H}_{4}\right), 7.42\left(\mathrm{~s}, 2 \mathrm{H} ; \mathrm{C}_{6} \mathrm{H}_{3}\right), 6.95(\mathrm{~s}, 1 \mathrm{H}$; $\left.\mathrm{C}_{6} \mathrm{H}_{3}\right), 4.88$ (s, $2 \mathrm{H}$; - $\left.\mathrm{PhCH} \mathrm{H}_{2} \mathrm{O}-\right), 4.14$ (m, $6 \mathrm{H}$; - $-\mathrm{PhOCH}_{2}$ - and $\left.\mathrm{PhCH}_{2}-\mathrm{OCH}_{2}-\right), 3.81$ (s, $2 \mathrm{H}$; $\left.-\mathrm{CH}_{2} \mathrm{O}-\right)$, 3.38-3.66 (m, $648 \mathrm{H}$; $-\mathrm{OCH}_{2}$ - in PEG dendron), 3.33 (s, $12 \mathrm{H}$; $\left.-\mathrm{OCH}_{3}\right), 2.25-2.40$ (m, $3 \mathrm{H} ; \mathrm{CH}), 1.25-1.91$ (m, $24 \mathrm{H}$; alkyl chain), $0.86\left(\mathrm{t}, 6 \mathrm{H}\right.$; $-\mathrm{CH}_{3}$ in alkyl chain), -3.13 (s, $2 \mathrm{H} ; \mathrm{NH})$.

Synthesis of 14: $8(100 \mathrm{mg}, 67 \mu \mathrm{mol})$ and manganese(II) chloride tetrahydrate $(270 \mathrm{mg}, 1.35 \mathrm{mmol})$ were dissolved in DMF $(20 \mathrm{~mL})$ and refluxed for $14 \mathrm{hrs}$. The mixture was extracted with ethyl acetate from water, and the organic phase was collected. Removing solvent by evaporation, the crude product was separated by flash column chromatography, and purified by washing with $\mathrm{MeOH}$ following hexane to afford $14(21 \mathrm{mg}$, $22 \%)$ as red-purple liquid. UV-vis $\left(\mathrm{CHCl}_{3}\right): \lambda_{\max } 337,373,474$, 572, $604 \mathrm{~nm} ;\left(\mathrm{H}_{2} \mathrm{O}\right): \lambda_{\max }$ 373, 393, 461, $559 \mathrm{~nm} ; \mathrm{MS} m / e$ 1537.6 .

Synthesis of 15: 13 (4 mg, $2.5 \mu \mathrm{mol})$ and manganese(II) chloride tetrahydrate ( $20 \mathrm{mg}, 50 \mu \mathrm{mol}$ ) were dissolved in DMF $(20 \mathrm{~mL})$ and refluxed for $12 \mathrm{hrs}$. The mixture was extracted with ethyl acetate from water, and the organic phase was collected. Removing solvent by evaporation, the crude product was separated by flash column chromatography, and purified by washing with $\mathrm{MeOH}$ following hexane to afford $15(2.07 \mathrm{mg}, 49 \%)$ as purple solid. UV-vis $\left(\mathrm{CH}_{2} \mathrm{Cl}_{2}\right): \lambda_{\max } 369,471,569,601 \mathrm{~nm}$; $\left(\mathrm{H}_{2} \mathrm{O}\right): \lambda_{\max } 365,461,560,596 \mathrm{~nm}$; MS m/e 1649.96.

\section{Result and Discussion}

The synthesis of amphiphilic porphyrin derivatives were accomplished as following. For the synthesis of PEG dendron (4), tri(ethylene glycol) monomethyl ether was reacted with methallyl dichloride in the presence of $\mathrm{NaH}$, and then methallyl group was converted to hydroxyl group using hydroboration reaction to obtain the $1^{\text {st }}$ generation PEG dendron (2). Compound $\mathbf{2}$ was again reacted with methallyl dichloride in the same manner with 


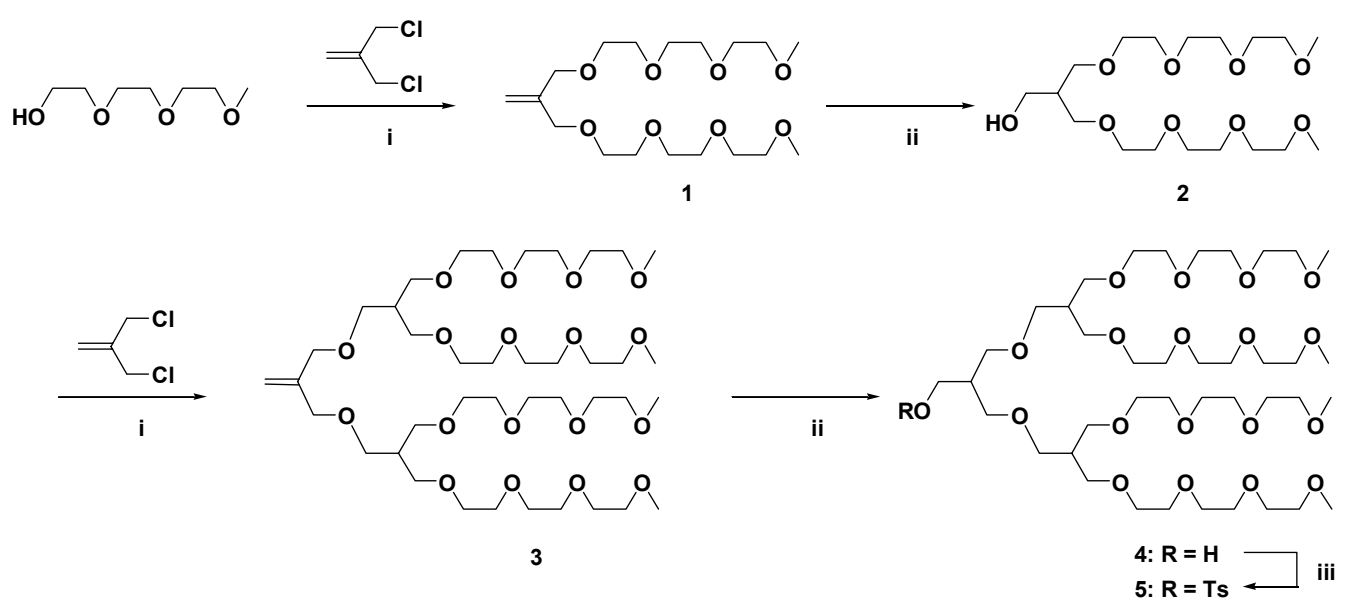

Scheme 1. Synthetic procedures of PEG dendron. i) NaH, THF, $65^{\circ} \mathrm{C}, 24 \mathrm{hr}$; ii) $\mathrm{BH}_{3}, \mathrm{H}_{2} \mathrm{O}_{2}, \mathrm{NaOH}, \mathrm{THF}, 0{ }^{\circ} \mathrm{C}, 24 \mathrm{hr}$; iii) $p$-toluene sulfonyl chloride, pyridine, $\mathrm{CH}_{2} \mathrm{Cl}_{2}, 25^{\circ} \mathrm{C}, 5 \mathrm{hr}$
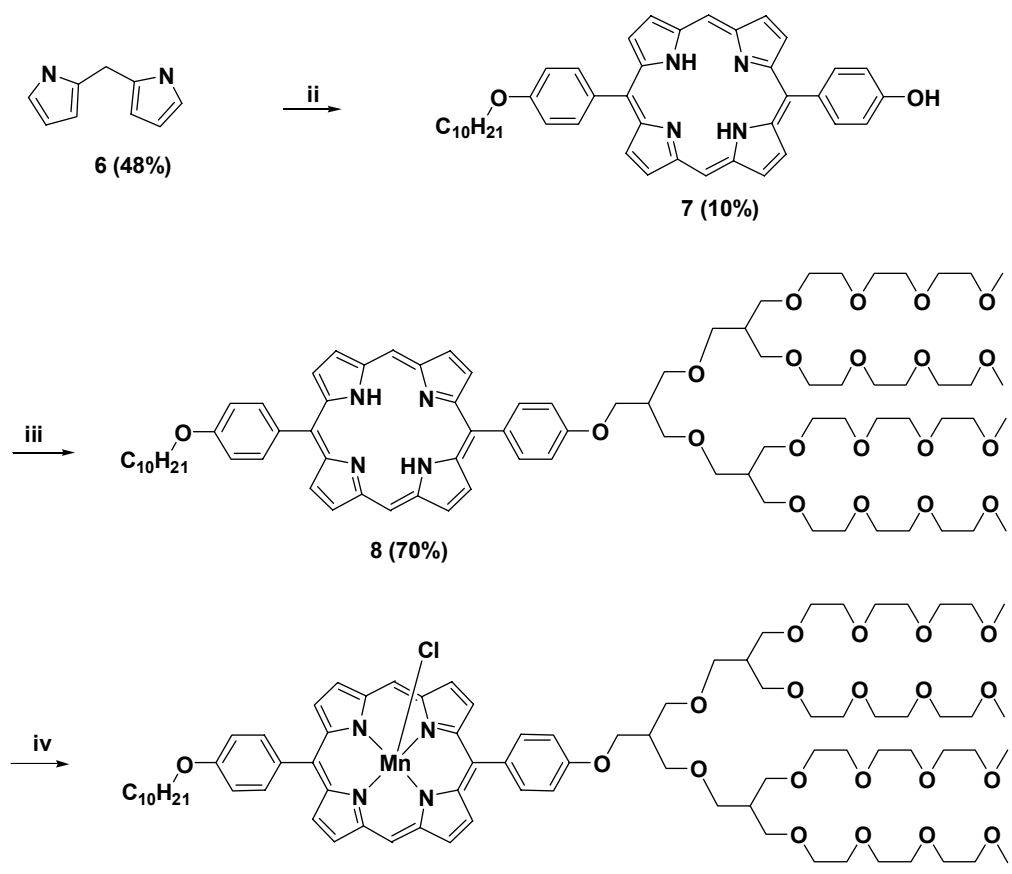

$14(21 \%)$

Scheme 2. Synthetic procedures of monoalkyl-substituted amphiphilic porphyrin (14). i) paraformaldehyde, acetic acid, $\mathrm{CH}_{2} \mathrm{Cl}_{2}, 25^{\circ} \mathrm{C}, 16 \mathrm{hr}$; ii) 4- $n$-decyloxybenzaldehyde, 4-hydroxybenzaldehyde, $\mathrm{BF}_{3} \cdot \mathrm{Et}_{2} \mathrm{O}$, chloranil, $\mathrm{CH}_{2} \mathrm{Cl}_{2}, \mathrm{MeOH}, 25^{\circ} \mathrm{C}, 20 \mathrm{hr}$; iii) 5, $\mathrm{K}_{2} \mathrm{CO}_{3}, \mathrm{DMF}, \mathrm{reflux}, 2 \mathrm{hr}$; iv) $\mathrm{MnCl}_{2} \cdot 4 \mathrm{H}_{2} \mathrm{O}$, DMF, reflux, $14 \mathrm{hr}$

tri(ethylene glycol)monomethyl ether to obtain 4. Finally, the core hydroxyl group was converted to toluenesulfonyl group for the coupling with porphyrin derivatives (Scheme 1). Porphyrins were prepared by the condensation and successive oxidation reactions between dipyrromethane (6) and appropriate aldehydes under acidic condition, where the $p$-chloranil was used as an oxidant. For the synthesis of monoalkyl substituted porphyrin (7), 4- $n$-decyloxybenzaldehyde and 4-hydroxybenzaldehyde were used as starting materials (Scheme 2). On the other hand, 3,5-dihydroxybenzaldehyde and 4-carboxymethylbenzaldehyde were used as starting materials for the synthesis of 9. Alkyl chain was introduced to 9 to obtain 10, which was re- duced to get dialkyl-substituted porphyrin having hydroxyl group (11) (Scheme 3). Finally, 5 was conjugated to the porphyrin units with alkaline mediated coupling reaction to obtain amphiphilic porphyrin derivatives, which were characterized by ${ }^{1} \mathrm{H}$ NMR and MALDI-TOF-MS analysis. To obtain manganese coordinated compounds, porphyrin derivatives ( 8 and 13) and manganese(II) chloride tetrahydrate were dissolved in DMF and then refluxed for $12 \mathrm{hrs}$. Thus obtained manganese (III) coordinated amphiphilic porphyrin derivatives (14 and 15) were characterized by MALDI-TOF-MS and UV-vis absorption.

All amphiphilic porphyrin derivatives $(\mathbf{8}, \mathbf{1 3}, \mathbf{1 4}$, and 15) 

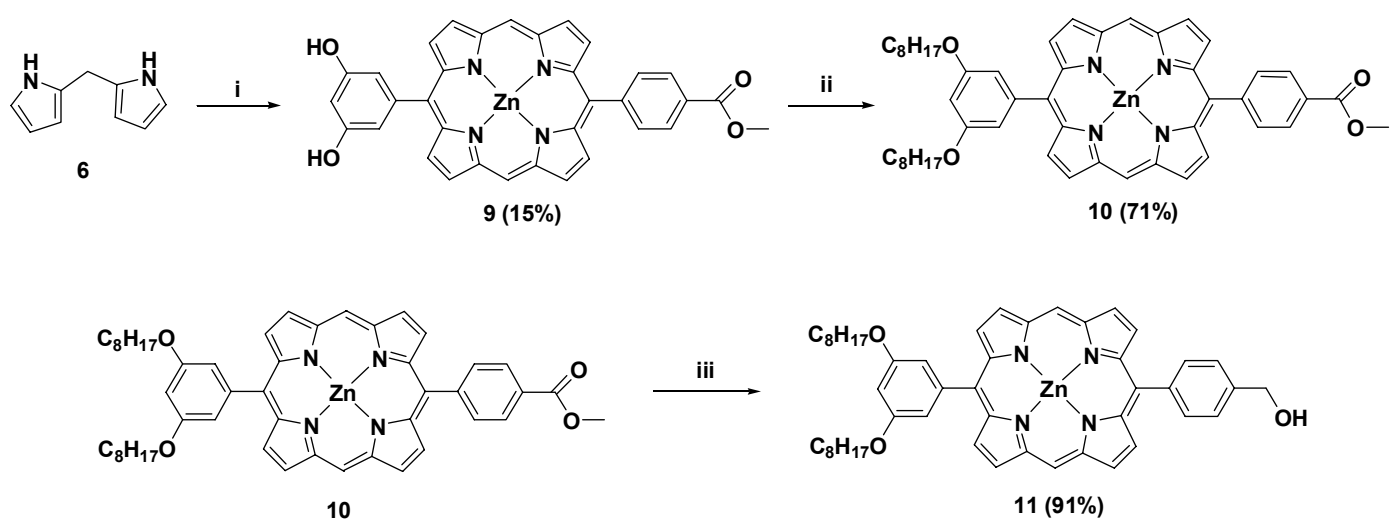

10

$11(91 \%)$

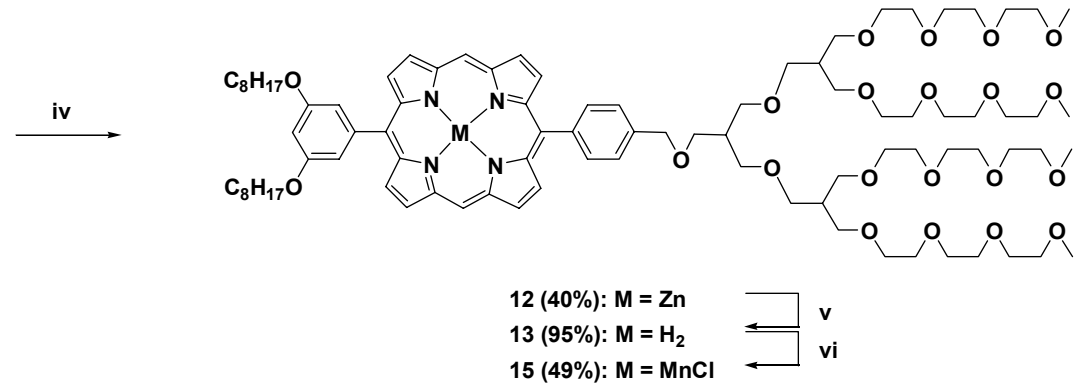

Scheme 3. Synthetic procedures of dialkyl-substituted amphiphilic porphyrin (15). i) 3,5-dihydroxybenzaldehyde, 4-carboxybenzaldehyde, $\mathrm{BF}_{3} \cdot \mathrm{Et}_{2} \mathrm{O}$, Chloranil, $\mathrm{Zn}(\mathrm{OAc})_{2}, \mathrm{CH}_{2} \mathrm{Cl}_{2}, \mathrm{MeOH}, 25^{\circ} \mathrm{C}, 20 \mathrm{hr}$; ii) 1-bromooctane, 18-crown-6 ether, $\mathrm{K}_{2} \mathrm{CO}_{3}, \mathrm{THF}$, reflux, $25 \mathrm{hr}$; iii) LiAlH 4 , THF, 0 to $25^{\circ} \mathrm{C}, 1 \mathrm{hr}$; iv) 5 , 18-crown-6-ether, $\mathrm{K}_{2} \mathrm{CO}_{3}$, THF, reflux, $48 \mathrm{hr}$; v) TFA, $\mathrm{CH}_{2} \mathrm{Cl}_{2}, 25{ }^{\circ} \mathrm{C}, 5 \mathrm{~min}$; vi) $\mathrm{MnCl}_{2} \cdot 4 \mathrm{H}_{2} \mathrm{O}, \mathrm{DMF}$, reflux, $12 \mathrm{hr}$

exhibited good solubility to aqueous medium as well as hydrophobic solvents such as $\mathrm{CHCl}_{3}$ or $\mathrm{CH}_{2} \mathrm{Cl}_{2}$. Porphyrin derivatives show characteristic absorption around $400-500 \mathrm{~nm}$ (Soret bands) and 550 - $650 \mathrm{~nm}$ (Q-bands). Compound 8 showed absorption maximum at $411 \mathrm{~nm}\left(\varepsilon=3.3 \times 10^{5}\right)$ and $543 \mathrm{~nm}$ in $\mathrm{CHCl}_{3}$. By coordination of manganese to 8 , the UV-vis absorption of both Soret and Q-band was significantly changed to the typical absorption of manganese porphyrin (Figure 1a). Compound 14 showed large absorptions at 337, 373, $474(\varepsilon=7.24 \times$ $\left.10^{4}\right), 572$, and $604 \mathrm{~nm}$. Similar phenomena were also observable with compound 15 (Figure 1b). On the other hand, although all amphiphilic porphyrin derivatives exhibited very good solubility to aqueous medium, they showed significant broadness and decrease of maximum intensity of absorption in aqueous solution. These observations possibly indicate the formation of supramolecular assembly through $\pi-\pi$ interactions among porphyrin unit. Therefore, the solutions of 14 and 15 were drop casted and subjected to electron microscopy. As a result, both 14 and 15 was exhibited formation of spherical micellar structures with diameters about $20 \mathrm{~nm}$ (Figure 2). Considering the molecular structures of 14 and 15, hydrophilic PEG dendrons can be located onto the periphery of the micellar structure and hydrophobic porphyrin units can form micellar core. Because the PEG is the most widely utilized biocompatible polymeric segment, we can expect that these materials can be utilized as a platform of bioimaging tools. Recently, noninvasive diagnostic techniques, such as computed tomography (CT), positron emission tomography (PET), and magnetic resonance imaging (MRI), are attracting increasing attention for the improvement of patient's quality of life. Among those techniques, MRI is one of the most powerful medical diagnostic tools. The MR image is generated from the difference of proton relaxation time between normal and abnormal tissues. To improve visualization of abnormal lesions, MRI examinations require the use of contrast agent. There are two different types of contrast agent used for the purpose of MR image enhancement. ${ }^{8}$ One type of contrast agent uses paramagnetic ions, and the other uses iron oxide nanoparticles. The paramagnetic ions gave brightness of MR images by shortening of the longitudinal relaxation time, $\mathrm{T}_{1}$, of protons. Alternatively, iron oxide nano-particles gave darkness of MR images by shortening of $\mathrm{T}_{2}$ relaxation times of neighboring protons. Although iron oxide nanoparticles have very high sensitivity, there are several disadvantages of $\mathrm{T}_{2}$ contrasted $\mathrm{MR}$ images. The darkening of image is less sensitive than $T_{1}$ contrast images, because the darkness can be resulted in various pathogenic conditions such as bleeding or calcification. Furthermore, superparamagnetic agent induces perturbation of the magnetic field on disease lesion as well as neighboring normal tissues. On the other hand, $\mathrm{T}_{1}$ contrast agents also have several drawbacks to improve their clinical availability. Clinical contrast agents currently being used include chelates to reduce toxic side effect of the metal ions. Low molecular weight MRI contrast agents diffuse rapidly from blood vessels into the interstitial space and are excreted from the body very rapidly. To achieve long circulation time in blood vessel, high molecular weight compounds have been developed in which metal ion-ligand complexes are covalently bound to several polymers, such as albumin, dextran, and polylysine. ${ }^{9}$ Although the stability in blood stream can be improved 
(a)

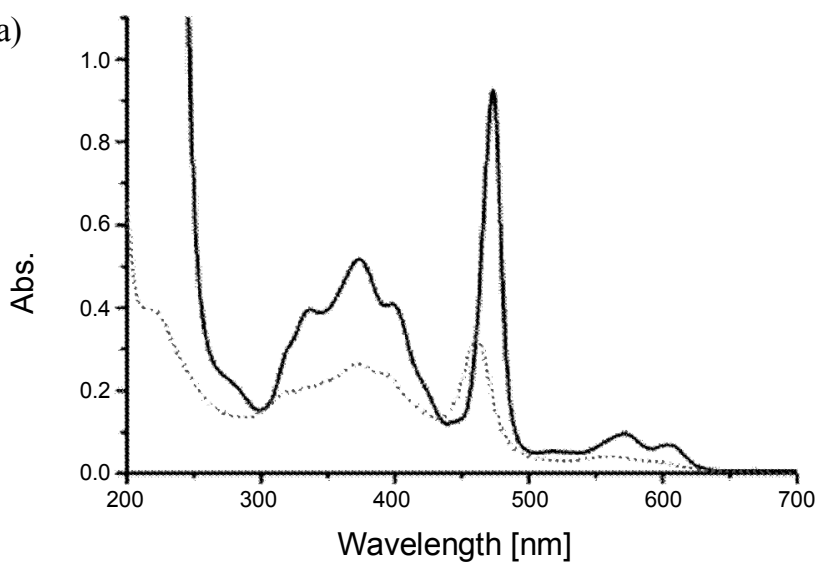

(b)

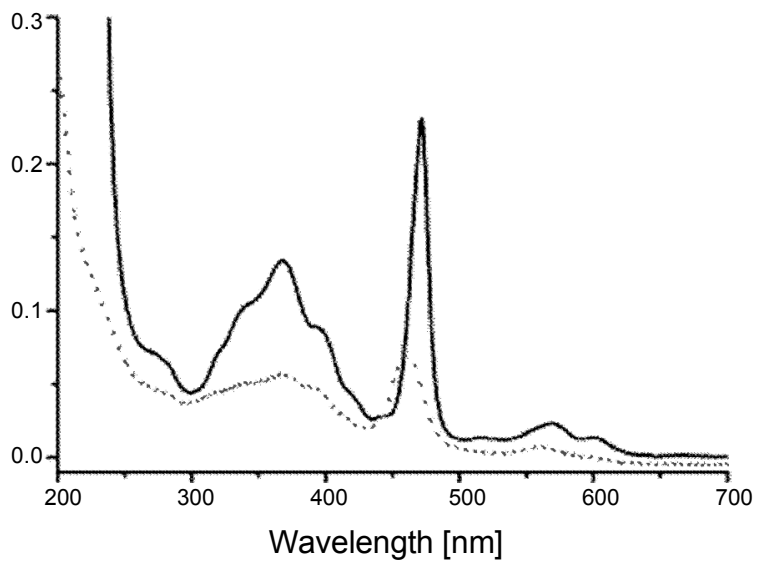

Figure 1. UV-vis absorption spectra of $\mathbf{1 4}$ and $\mathbf{1 5}$ in $\mathrm{CHCl}_{3}$ (solid line) and $\mathrm{H}_{2} \mathrm{O}$ (dotted line).
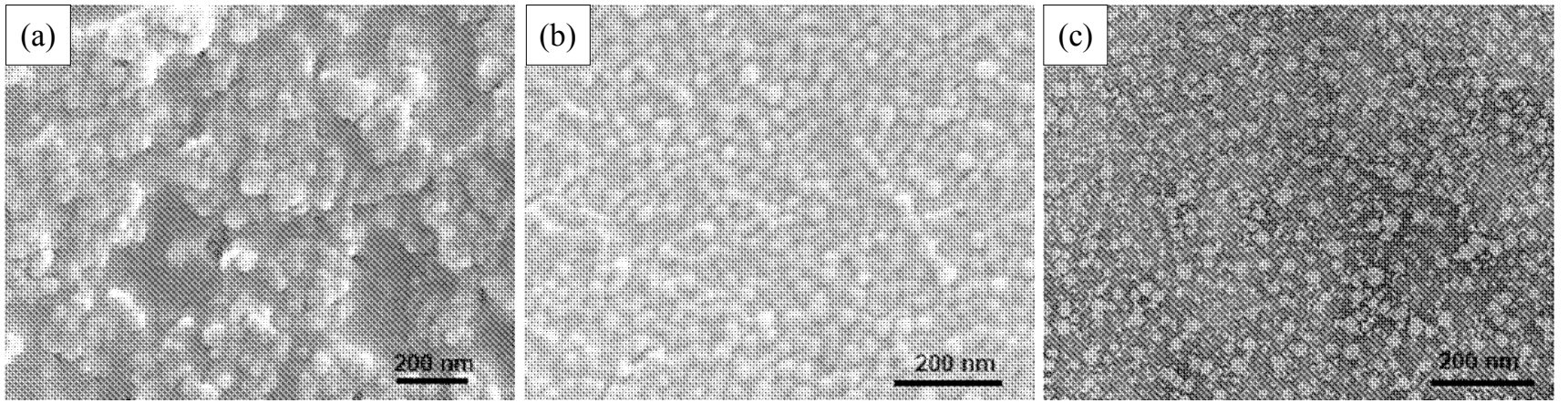

Figure 2. Electronic microscope images of supramolecular micelles. (a) And (b) SEM image of $\mathbf{1 4}$ and 15, respectively, (c) TEM image of $\mathbf{1 5}$.

by covalent conjugation of the complexes and polymers, slow clearance and long term toxic side effect would be another problem. Therefore, the Mn(III)-porphyrin derivative supramolecular micelle possibly has characteristics as $T_{1}$ contrast enhancing nanoparticle. And also, the excretion of the supramolecular micelle would be relatively easy because the molecular weight of $\mathrm{Mn}$ (III)-porphyrin derivative is small and micelle can be dissociated under dilution. As preliminary experiment, we have measured the $T_{1}$ relaxation time of aqueous medium in the presence of compound 14 . As a result, the $T_{1}$ relaxation time was $80.25 \mathrm{~ms}$ at the concentration of $2.47 \mathrm{mM}$. Considering the commercially available Gd-DTPA has about $4.5 \mathrm{mM}^{-1} \mathrm{sec}^{-1}$ of $\mathrm{T}_{1}$ relaxivity, the $\mathrm{Mn}$ (III)-porphyrin derivative supramolecular micelles have sufficiently high $\mathrm{T}_{1}$ relaxivity to utilize as MRI contrast agent. ${ }^{10}$

\section{Conclusion}

We have synthesized manganese coordinated amphiphilic porphyrin derivatives, which formed supramolecular micelle in aqueous medium. The formation of spherical micellar structures with diameters about $20 \mathrm{~nm}$ was observed by SEM measurement. The $\mathrm{T}_{1}$ relaxation time of aqueous medium was drastically decreased in the presence of compound 14, indicating that the supramolecular micelle has strong possibility to use as a $T_{1}$ contrast agent. And also, because the large hydrodynamic volume of supramolecular micelle possibly enhances tumor localization through the enhanced permeability and retention (EPR) effect, ${ }^{9}$ the supramolecular micelle would be very useful for the detection of malignant disease. Detailed evaluation and modifications are currently underway to test clinical availability.

Acknowledgments. This research was supported by National R\&D Program through the National Research Foundation of Korea(NRF) funded by the Ministry of Education, Science and Technology (2009-0078174) and KRIBB Research Initiative Program. K. Choi and D.-H. Lee acknowledge fellowships from the BK21 program from the Ministry of Education, Science and Technology.

\section{References}

1. a) Gryco, D. T. Eur. J. Org. Chem. 2002, 1735. b) Johnson, A. W. Chem. Soc. Rev. 1980, 9, 125.

2. a) Li, W.-S.; Aida, T. Chem. Rev. 2009, 109, 6047. b) Jang, W.-D.; Lee, C.-H.; Choi, M.-S.; Osada, M. J. Porphyr. Phthalocya. 2009, 13, 787. c) Choi, M.-S.; Yamazaki, T.; Yamazaki, I.; Aida, T. Angew. Chem. Int. Ed. 2003, 43, 150.

3. a) Macdonald, I. J.; Dougherty, T. J. J. Porphyr. Phthalocya. 2001, 5, 105.b) Takeuchi, Y.; Ichikawa, K.; Yonezawa, S.; Kurohane, K.; Koishi, T.; Nango, M.; Namba, Y.; Oku, N. J. Control Release 2004, 97, 231. c) Merclin, N.; Bramer, T.; Edsman, K. J. Control Release 2004, 98, 57. d) Arnida, Nishiyama, N.; Kanayama, N.; Jang, W.-D.; Yamasaki, Y.; Kataoka, K. J. Control. Release 2006, 115, 208. e) Jang, W.-D.; Nakagishi, Y.; Nishiyama, N.; Kawauchi, S.; Morimoto, Y.; Kikuchi, M.; Kataoka, K. J. Control Release 
2006, 113, 73. f) Nishiyama, N.; Iriyama, A.; Jang, W.-D.; Miyata, K.; Itaka, K.; Inoue, Y.; Takahashi, H.; Yanagi, Y.; Tamaki, Y.; Koyama, H.; Kataoka, K. Nat. Mater. 2005, 4, 934. g) Kim, J.; Yoon, H.-J.; Kim, S.; Wang, K.; Ishii, T.; Kim, Y.-R.; Jang, W.-D. J. Mater. Chem. 2009, 19, 4627.

4. a) Saini, S. K.; Singh, R. Magnetic Resonance imaging 1995, 13, 985. b) Brandon, E. J.; Miller, J. S. Inorgan. Chem. 1998, 37, 2792. c) Pan, D.; Caruthers, S. D.; Hu, G.; Senpan, A.; Lanza, G. M. J. Am. Chem. Soc. 2008, 130, 9186.

5. Charvet, R.; Jiang, D. L.; Aida, T. Chem. Commun. 2004, 2664.

6. a) Kabanov, A. V.; Chekhonin, V. P.; Alakhov, V. Y.; Btrakova, E. V.; Lebedev, A. S.; Melik-Nubarov, N. S.; Arzhakov, S. A.; Levashov, A. V.; Morozov, G. V.; Severin, E. S.; Kabanov, V. A. FEBS
Lett. 1989, 258, 343. b) Gabizon, A. A. Adv. Drug Delivery Rev. 1995, 16, 285. c) Maeda, H.; Wu, J.; Sawa, T.; Matsumura, Y.; Hori, K. J. Control Release 2000, 65, 271.

7. Jarayaman, M.; Fréchet, J. M. J. J. Am. Chem. Soc. 1998, 120, 12996.

8. Na, H. B.; Hyeon, T. J. Mater. Chem. 2009, 19, 6267.

9. a) Schmiedl, U.; Ogan, M.; Paajanen, H.; Marotti, M.; Crooks, L. E.; Brito, A. C.; Brasch, R. C. Radiology 1987, 162, 205. b) Wang, S. C.; Wikstroem, M. G.; White, D. L.; Klaveness, J.; Holtz, E.; Rongved, P.; Moseley, M. E.; Brasch, R. C. Radiology 1990, 175, 483. c) Schuhmann-Giampieri, G.; Schmitt-Willich, H.; Frenzel, T.; Press, W. R.; Weinmann, H. J. Invest. Radiol. 1991, 26, 969. 10. Stanisz, G. J.; Henkelman, R. M. Mag. Reson. Med. 2000, 44, 665. 